\title{
Possible Effect of Vaccination against Trichophyton mentagrophytes Infection in a Swedish Fox Farm
}

Superficial infections caused by dermatophytes are commonly called "ringworm" due to the typical form of the skin lesions. The different dermatophytes are usually best adapted to one or a few animal species but can be transmitted to other species. The infection frequently spreads to humans in direct contact with the infected animals, which makes dermatophytosis a zoonotic infection (Chmel et al. 1975, Hauck 1980).

The dermatophytes most frequently isolated from farmed foxes are reported to be Trichophyton mentagrophytes although both Trichophyton verrucosum and Microsporum canis have been isolated on occasion (Englund et al. 1988). Ringworm infections can be a serious problem in fox farms since the lesions cause severe damage to the pelts. In the USSR dermatophytosis is reported to be a widespread infection in farmed foxes ( $\mathrm{Ni}$ kiforov 1978). Only a few outbreaks are reported from Scandinavia in spite of the fact that almost two thirds of the world production of fox skins originate from Scandinavian fur farms (Englund et al. 1988).

The traditional treatment for ringworm infections in farmed foxes is by use of griseofulvin mixed with the feed twice weekly for several weeks (Henriksen 1984). This method has proven to be both expensive and laborious in Sweden as the drug is commercially available here only in tablet form (Lamoryl ${ }^{\circledR}$, Lövens läkemedel, Malmoe, Sweden). An attenuated live vaccine, Mentavak (Medexport, Moscow, USSR), has recently been developed, and frequently used, in the USSR for immunoprophylaxis against Trichophyton mentagrophytes infections in fox and rabbit. The same company has produced a similar vaccine against infection with $T$. verrucosum in cattle, LTF-130, which has been evaluated with good results in Swedish and Norwegian field trials ( $\mathrm{Aa}$ modt et al. 1982, Pehrson \& Törnqvist 1983, Törnqvist et al. 1985, Gudding \& Naess 1986).

In February 1987, T. mentagrophytes was isolated from 4 adult foxes, with skin lesions, belonging to 2 neighbouring fox farms housing silver fox (Vulpes vulpes) and blue fox (Alopex lagopus). The clinical symptoms and laboratory methods have been described earlier (Englund et al. 1988). The farms were very closely situated and the owners had a close co-operation so the farms were, from an epidemiological point of wiew regarded as one. In July 1987 the infection had spread to pups born earlier during the spring. Approximately $5 \%$ of the pups had visible ringworm lesions. All foxes, 106 adult as well as 250 pups, were then vaccinated, according to the producers recommendations, intramuscularily with Mentavak on 2 occasions with 8 days interval. Animals without visible ringworm were injected with the recommended prophylactic dose, $2 \mathrm{ml}$ to adults and $1 \mathrm{ml}$ to pups. All animals with clinical symptoms of dermatophytosis were given the higher "therapeutic dose", $3 \mathrm{ml} /$ adult and $2 \mathrm{ml} / \mathrm{pup}$. The owners and their families had all become 
infected and had to undergo medical treatment for several weeks.

No new cases appeared after the second vaccination was completed and 10 weeks later the clinical lesions had healed in all foxes but one, which was subsequently eutanized. The farms were thoroughly cleaned. All cages and nestboxes were washed and the soil under the cages was shifted. Cages, nestboxes and ground were then soaked with idofor-containing disinfectant. Thirty-nine adult foxes brought into the farms during the winter were vaccinated, on arrival, with $2 \times$ $2 \mathrm{ml}$ Mentavak each.

In March 1988, 8 months after the first vaccination all animals were still free from visible ringworm lesions. Ten pulled hair samples from 10 clinically healthy foxes vaccinated as pups were analysed. In 2 of the samples growth of Trichophyton mentagrophytes could be detected.

Ten samples of soil were analysed in June '88. Nine were taken underneath cages where foxes with visible ringworm lesions had been housed and 1 from a heap of sand nearby, were the two most severely affected pups had been allowed out to play the previous summer. All samples taken near the fox cages, where the ground had been cleaned, were negative. In the 1 sample from the "playground", which had been missed out during the cleaning, T.mentagrophytes was isolated.

Due to the 2 positive hair samples and the positive soil sample it was concluded that the infective agent was still present within the farm area, posing a risk of infection in unvaccinated foxes. All breeders had been vaccinated the previous year so the animals at risk were the pups born during the spring months in 1988. All 850 pups were, as a consequence, vaccinated during July with 1 $\mathrm{ml}$ Mentavak each, twice with 10 days interval. No pups or adult foxes had any clinical symptoms of ringworm either before or after the vaccinations.

No signs of ringworm could be observed during the following autumn, winter or spring. No vaccination was performed on the pups born in 1989. All foxes in the farms, vaccinated adults as well as 800
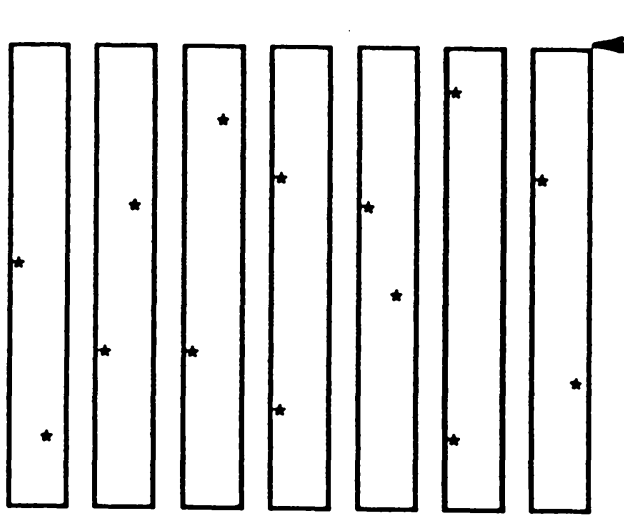

$60 \mathrm{~m}$
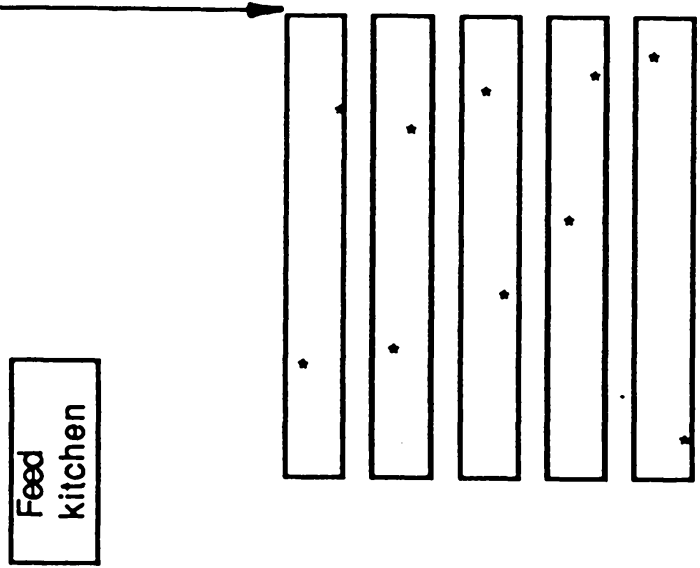

Figure 1. Map of the 2 fox farms affected by ringworm. * marks the locations where pulled hair samples were taken in October 1989. Distance between sheds is $4.5 \mathrm{~m}$. 
unvaccinated pups, remained free from any signs of ringworm.

During late October 1989, 15 months after the latest vaccinations, pulled hair samples were collected from 1 pup per litter in 24 out of the 160 litters (15\%). The sampling was done from all sheds as shown in Fig. 1. No growth of dermatophytes could be detected either by direct microscopy or by culturing of the samples.

The lack of proper controls in this field trial clearly limits the possibilities of drawing any definite conclusions from the results. The method of eradicating ringworm, caused by $T$. mentagrophytes, in fox farms by use of vaccination with Mentavak appears however to have been successful in this case. The findings of the microorganism still present in the farm and on the animals many months after the vaccinations without causing visible lesions is of importance to the fur farmers. The use of vaccination can probably minimise the losses in the affected farm since it arrests the spread of the clinical infection within the farm. Thorough cleaning of cages, nestboxes and ground is however essential for eliminating the infective agent from the premises to avoid reinfection as soon as the vaccination program is abolished. We feel that the preliminary results from the use in one Swedish farm indicate that a large scale study of Mentavac could be of interest for the future treatment of ringworm in fox farms.

\section{Acknowledgements}

We thank the local veterinarians, Mats Westman and Assa Bergvall for their assistance with vaccinations, clinical inspections and sampling.
Lena Englund, Roland Mattson and

Louise Treiberg Berndtson

Division of Fur Animals and Department of

Bacteriology, National Veterinary Institute, Uppsala, Sweden.

\section{References}

Chmel L, Buchvald J, Valentova M: Spread of Trichophyton mentagrophytes var. gran. infection to man. Int. J. of Dermatol. 1975, 14, 269-272.

Englund L, Treiberg L, Mattsson R: Ringworm in Swedish farmed and wild fox. Proc. IV Int. Congress in fur animal production (Canada) 1988, 196-203.

Gudding $R$, Naess, $B$ : Vaccination of cattle against ringworm caused by Trichophyton verrucosum. Amer. J. vet. Res. 1986, 47, 2415-2417.

Hauck H: Pet rodents as a source of dermatophytic infection in humans. Preusser (eds.): Medical Mycology, Zbl. Bakt. Suppl. 8, Gustav Fisher Verlag, Stuttgart, New York, 1980.

Henriksen P: Ringorm hos farm-ræve i Danmark. (Ringworm in farmed fox in Denmark). Dansk VetTidskr. 1984, 67, 98-99.

Nikiforov LI: Trikhofitiya serebristo-chernykh eisits i pestsov. (Trichophytosis of silver-grey and arctic foxes). Bulleten Vsesoyuznogo Ordena Lenina Instituta Experimental noi Veterinarii. (Bulletin of the All-Union Institute of Experimental Veterinary Medicine, Moscow), 1978, 32, 25-27.

Pehrson B, Törnpvist M: Försök med vaccination mot ringorm hos nötkreatur i mjölkproducerande besättningar. (Trials with vaccination against ringworm in dairy cattle). Svensk Veterinärtidning 1983, 35, 569-571.

Törnqvist M, Bendixen PM, Pehrson B: Vaccination against ringworm in specialized beefproduction. Acta vet. scand. 1985, 26, 21-29.

Aamodt $O$, Nass B, Sandvik $O$ : Vaccination of Norwegian cattle against ringworm. Zbl. Vet. Med. B, 1982, 29, 451-456.

(Received December 14, 1989; accepted February 23, 1990).

Reprints may be requested from: Lena Englund, National Veterinary Institute, P. O. Box 7073, SVA S-750 07 Uppsala, Sweden. 